\title{
Measuring Regional Economic Growth In Jordan
}

\author{
https://doi.org/10.21272/sec.4(3).125-130.2020.
}

Jameel Aljaloudi, ORCID: https://orcid.org/0000-0002-2924-4119

Dr., Professor, Department of Planning and Project Management, College of Business, Al-Balqa Applied University, Jordan

\begin{abstract}
This research aims to measure the regional disparities in Jordan's economic growth during 2010-2017. As an indicator to measure the economic growth in each region is the regional factor $(\mathrm{R})$ adopted, and for estimation the regional factor is the Shift and Share method used. This method is widely used by geographical economist. The annual average of household income, as economic indicator, to estimate the regional factor in this study will be adopted. Data on annual household income were taken from the expenditure and income surveys prepared by the Jordanian General Statistics Department in year 2010 and year 2017. The results of this study indicate that economic growth in Irbid region and Mafraq region was greater than the national growth, while the rest of the regions have had much slower economic growth compared to national growth during the study period. Expect Amman region, the capital of Jordan, showed similar economic growth to national level. The results of the research indicate that the region's share of income increased for regions that achieved high economic growth and in return this share was reduced to the values that showed low growth and lower than the rate of national economic growth. The least economically developed regions are the regions in the south of the country, despite the development policies in the field of balanced regional development, but because of the lack of infrastructure, they are still unable to reduce the development gap between the regions in Jordan. The study recommended the need for the government to enable the regions to accelerate regional development as well as reduction in the development gap between them by devolving administrative and financial powers from the central level to the regional level. It also recommended the need to support investment, especially in the less developed regions.
\end{abstract}

Keywords: economic growth, regional economics, income distribution, development planning, decentralization.

\section{JEL Classification: P25.}

This work is licensed under a Creative Commons Attribution 4.0 International License.

Cite as: Aljaloudi, J. (2020). Measuring Regional Economic Growth In Jordan. SocioEconomic Challenges, 4(3), 125-130. https://doi.org/10.21272/sec.4(3).125-130.2020.

(C) The Authors, 2020. This article is published with open access at Sumy State University.

\section{Introduction}

Since the beginning of the 1970s, the goal of regional development and reducing regional disparities has been one of the goals of development plans in Jordan. Jordan has been divided administratively and developmentally into 12 provinces since 1986. Since taking office in 2000, the king has directed successive governments to achieve balanced regional development and to reduce the disparity in development in the regions. The aim of this study is to measure the annual growth rates of the average annual income of households in different provinces during the period 201-2017. It also aims to measure the regional Factor (R) for each province in order to clarify the extent of economic growth and compare it to the size of the country's economic growth. The average annual income of the family was adopted as a measure of the level of growth and development in the kingdom's regions. The study was based on the 2010 household expenditure and income survey data and the 2017 household expenditure and income survey published by the Jordan General Statistics Department (www.dos.gov.jo). To measure regional factor, the shift and share method has been adopted. which are used by economists and social workers in the developed and developing world. this study is original because it is the first study that measures the level of regional development by using shift and share methods, while previous studies dealt with development disparities between the regions, and they used different methods such as Gini coefficient, covariance coefficient and factor analysis. 
SocioEconomic Challenges, Volume 4, Issue 3, 2020

ISSN (print) - 2520-6621, ISSN (online) - 2520-6214

\section{Theoretical Frame Work and Empirical Studies}

Intellectual views differed in the concept of regional development and in the extent or absence of economic and social disparity between the regions. The classical economic theory does not believe in the existence of the phenomenon of developmental disparity between regions over time, due to their belief in the free movement of production factors between regions (the absence of any natural, administrative, economic or political obstacles) (Richardson, 1973) and (Ray, 2007). On the contrary, there are a number of researchers who believe that there is a discrepancy in the abundance of production elements between regions on the one hand, and the inability to transfer production factors between regions on the other hand. This would lead to a developmental discrepancy between the regions measured by indicators such as (average per capita income, prices of production factors, etc.) (Myrdal, 1957). According to the endogenous growth theory, the rational use of the economic resources possessed by the region can provide a key to achieving economic growth and thus reducing the gap (trickle down), Hirschman (1957) and Perroux (1964). However, many authors note that differences may persist due to the differences in resources granted between the developed region and the underdeveloped regions, $g$ due to insufficient capacity to benefit from these widespread effects.

There are researchers who have analyzed the causes of the disparity and set development policies to reduce them and understand the dynamics of agglomeration and factor flows and regional economic growth. (Sheppard and others, 2004; Krugman, 1990). Krugman (1998) and Fujita) .

Many field studies have been conducted to study the developmental disparity between regions in a number of developed and developing countries. These studies used different methods to measure this variance. As example: Oliver and Streicher 2004, measured the Changes in Regional Competitiveness over Time, and they used A Shift-Share Regression model. Helene and Midelfart (2004) explained the regional income inequality in Norway, and used the production function equation model to analysis of regional productivity and income disparities. Villaverde and Maza (2009) measured the regional economic disparities in the European Union (EU) by using the convergence method. This method is also used by Breau \& Saillant (2016) to measure the Regional income disparities in Canada. Shantong Li, Fei Wang and Zhaoyuan Xu June 2016 conducted a study and used the Gini coefficient model to measure regional income disparity in china. Fritz and Gerhard Streicher (2004) Measured the changes in regional Competitiveness over time in Austria by using Shift-Share Regression model. Gennaioli et al. (2014) presented a model of convergence across 1.528 regions from 83 countries to compare the speed of per capita income convergence within and across countries. Bandare et al. (214) conducted an empirical study to measure regional disparities in Sri Lanka. It is mainly based on the well-established regional inequality analysis methods of sigma and beta convergence.

For Jordan, previous studies have measured regional inequality, based on a Gini coefficient estimate of average annual household expenditure before 2010. The (UNDP) and UNICEF in 2012 conducted a study to estimate the Gini coefficient . In their estimates, they used the annual average of household expenditure as indicator and it based on the results of the Household expenditure and income survey 2010 (HEIS). In 2012, Mansour analyzed the patterns and determinants of the level of economic well-being of the Jordanian household by estimating the gini coefficient for all regions in jordan. He used the average annual household expenditure as indictor, whose value was published in the HEIS surveys conducted in 2002, 2008 and 2010, by the department of Statistic in Jordanian (DOS).

The originality of this study is due to the estimation of the regional coefficient for each region in Jordan in order to measure the disparity in economic growth between the regions. The assessment process will be carried out by adopting the model of shift and share. The study also adopted the average annual household income index for calculation the regional factors. It also relied on the results of the (HEIS) conducted by the DOS in the years 2010 and 2017.

\section{The economic and population regional distributing in Jordan during 2010-2017}

Since 1986, Jordan has been administratively and developmentally divided into 12 provinces ( regions) (see Map 1). The decentralization law was passed in year 2015, under which an elected council was formed for each region. It has been given powers to develop the territory for the first time. And make recommendations in the selection and financing of development projects within the financial ceilings approved by the central government in its annual public budget and follow up the evaluation and implementation of these development projects. The aim of the administrative and political reform in the country was to participate the people of the 
regions in the development process in a way that ensures the realization of their needs, increased there welfare and to reduce the development gap between the regions in Jordan.

Map No. 1. Administrative regions in Jordan

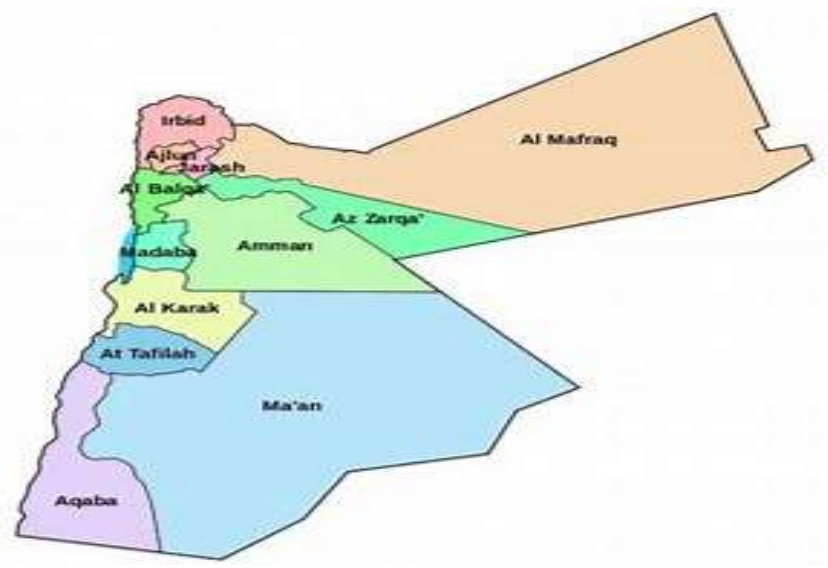

The legend of the region in Jordan:

1. Amman

2. Al-Balqa

3. Al-Zarqa

4. Maddaba

5. Irbid

6. Mafraq

7. Jarash

8. Ajloon

9. Karal

10. Tafelah

11. Maan

12. Aqaba

Source: https://www.bing.com/search?q=jordan+map+by+governorate+\&form=ANSPH1\&refig=9de42ec8a05b4b429f5a5edc5376b3f6\&pc=U531

The data in Table 1 show the relative distribution of income and population in the regions. It showed that the share of Amman region in income and population is the largest and increasing. It is followed by Irbid region in second and Mafraq region in third place. The rest of the regions showed a decrease in their share of income and population during the same period and the changes that occurred during the period 2010-2017.

Table 1. The change of regional income and population distribution in Jordan 92010-2017).

\begin{tabular}{|c|c|c|c|c|c|c|c|}
\hline \multicolumn{4}{|c|}{ Income distribution } & \multicolumn{4}{|c|}{ Population distribution } \\
\hline & 20.10 & 20.17 & $\begin{array}{l}\text { The } \\
\text { Change }\end{array}$ & & 20.10 & 20.17 & $\begin{array}{l}\text { The } \\
\text { Change }\end{array}$ \\
\hline Amman & 0.489 & 0.492 & + & Amman & 0.407 & 0.421 & + \\
\hline Balqa' & 0.055 & 0.051 & - & Balqa' & 0.067 & 0.063 & - \\
\hline Zarqa' & 0.124 & 0.120 & $\cdot$ & Zarqa' & .015 & 0.128 & - \\
\hline Madaba & 0.019 & 0.018 & - & Madaba & .025 & 0.024 & - \\
\hline Irbid & 0.153 & 0.167 & + & Irbid & .172 & 0.180 & + \\
\hline Mafraq & 0.034 & 0.044 & + & Mafraq & .042 & 0.048 & + \\
\hline Jerash & 0.024 & 0.019 & & Jerash & .027 & 0.028 & + \\
\hline Ajloun & 0.018 & 0.016 & & Ajloun & .022 & $0 . .020$ & - \\
\hline Karak & 0.037 & 0.034 & - & Karak & .035 & 0.036 & + \\
\hline Tafileh & 0.012 & 0.009 & - & Tafileh & .014 & 0.013 & - \\
\hline Ma'an & 0.015 & 0.014 & - & Ma'an & .018 & 0.016 & - \\
\hline Aqaba & 0.019 & 0.018 & - & Aqaba & .021 & 0.022 & + \\
\hline
\end{tabular}

Sources: 1. Department of statistic (2010), expenditure and income Household survey 2010, table 2-1, “. Amman - Jordan.

2. Department of statistic (2017), expenditure and income Household survey 2017, table 2-1, “. Amman - Jordan.

Figure 1 shows that the average annual income of the household has increased in all regions during 20102017, but unevenly a mange the regions. The household income was the highest in the Amman region and was the least in the Mafraq and the Jerash regions. 


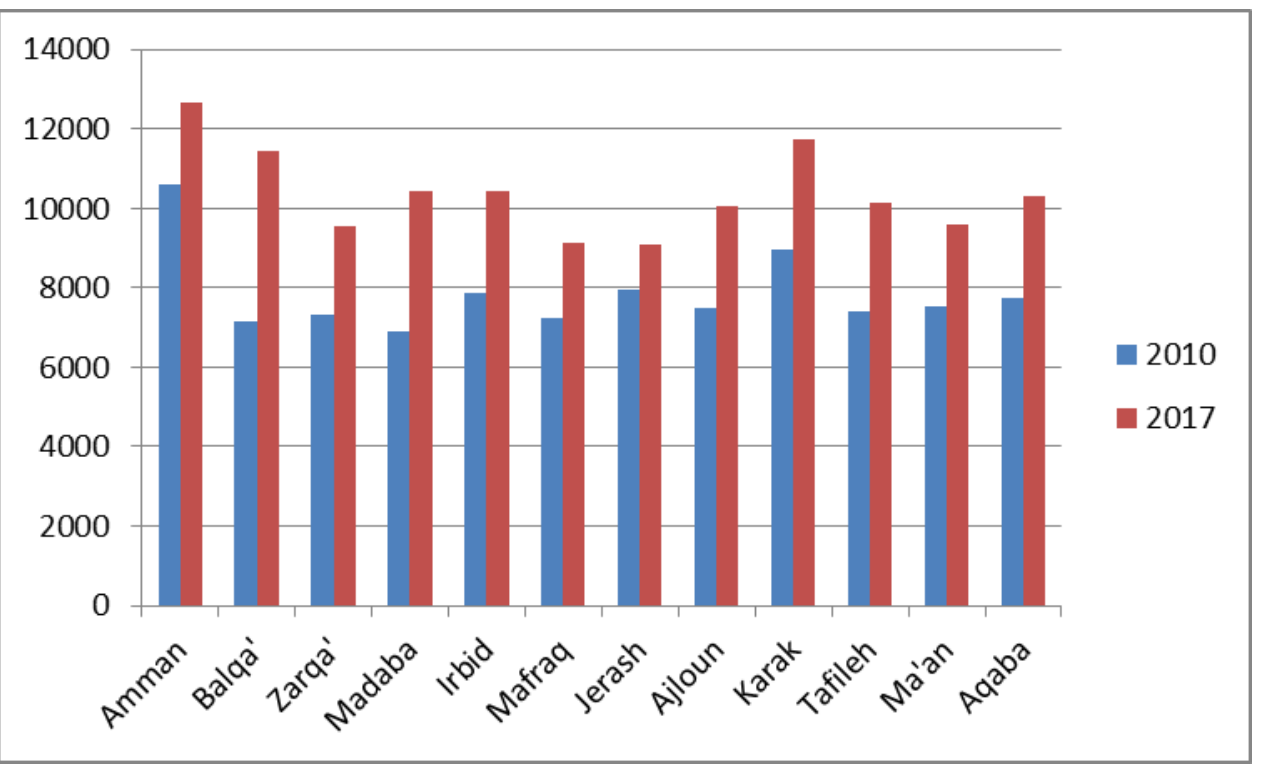

Figure 1. Annual Average of Household nominal income in yesr 2010 and 2017

Source: prepared by the author.

Figure 2 shows that the average annual income of household in the region of Amman is higher than the national average of the annual income of the household in 2010 and still the same position in 2017. But despite its increase in the remaining regions, these averages are still below the overall average in Jordan.

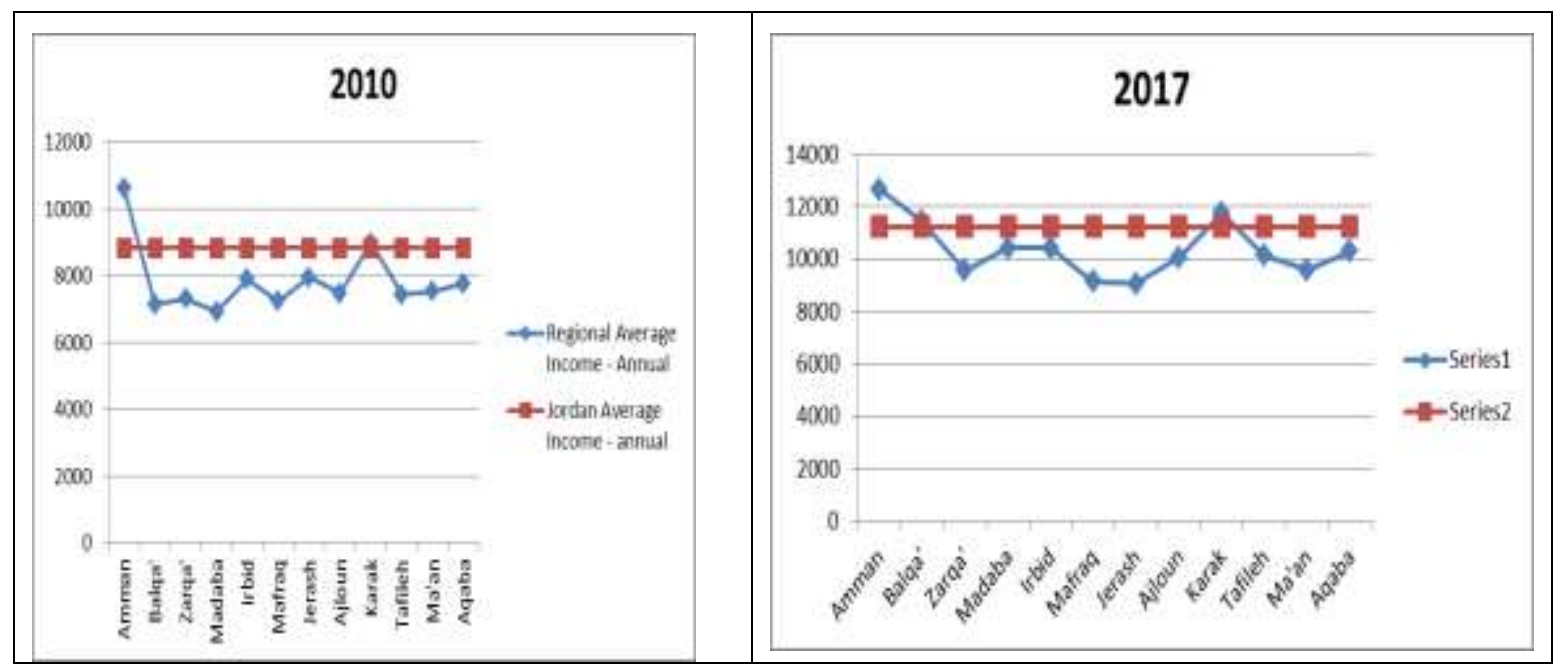

Figure 2. Annual Average of household income in Jordanians regions in 2010 and 2017

Source: prepared by the author.

\section{The Methodology}

The Shift and Share method will be used to estimate the region's coefficient, which measures the disparity in economic growth between regions on the one hand and compare it to the national growth rate on other hand. The shift-share analysis is a traditional, well known and often applied method and was applied to empirical analysis as early as in the 1960s and underwent numerous extensions and improvements in the 1970s ( Richardson, 1978). In estimating the model, where of the following economic indicators can be used, such as the household income or (income per capita), and number of economic companies and their employees. With regard to the economic indicators mentioned (excluding income and expenditure), there are no data published in HEIS 2010 and HEIS 2017. The average of nominal annual income of the household will be taken as an index.

The model (Mueller, 1976) is formulated as following: $R=\frac{b_{t}}{b_{o}}: \frac{B_{t}}{B_{0}}$ 
Where:

$\mathbf{R}$ is the regional factor; $\boldsymbol{b}_{\boldsymbol{o}, \boldsymbol{t}}$ : Total household income in the region in time 0 and $\mathrm{t} ; \boldsymbol{B}_{\boldsymbol{o}, \boldsymbol{t}}$ : Total Household income in the country in time 0 and $t$

If: $\mathbf{R}>\mathbf{1}$ that means the economic growth in the region is faster than the National economic growth;

$\mathbf{R}=\mathbf{1}$ that means the economic growth in the region is equal the National economic growth;

$\mathbf{R}<\mathbf{1}$ that means the economic growth in the region is lower than the National economic growth.

\section{The results}

Table 2 shows the results of estimating values of the regional factor for all Jordanian's regions. According to equation 1, the value of $(\mathrm{R})$ in Amman region is (1.005), which mean that the economic growth in Amman region was almost equivalent to national economic growth. But, the estimated regional factor for Mafraq region is (1.267) and for Irbid region (1.087), it means that these both regions were growing faster than the national average. The economic growth in the rest of the Jordanian regions were growing slower than the national average, while all estimated value are less than one.

Table 2. The calculated regional factor for Jordanian's region

\begin{tabular}{|l|c|}
\hline The Region & The regional factor ( R ) \\
\hline Amman & 1.005 \\
\hline Balqa' & 0.944 \\
\hline Zarqa' & 0.970 \\
\hline Madaba & 0.928 \\
\hline Irbid & 1.087 \\
\hline Mafraq & 1.267 \\
\hline Jerash & 0.794 \\
\hline Ajloun & 0.862 \\
\hline Karak & 0.894 \\
\hline Tafileh & 0.756 \\
\hline Ma'an & 0.901 \\
\hline Aqaba & 0.951 \\
\hline Jordan & 1.000 \\
\hline
\end{tabular}

Source: calculated by the author.

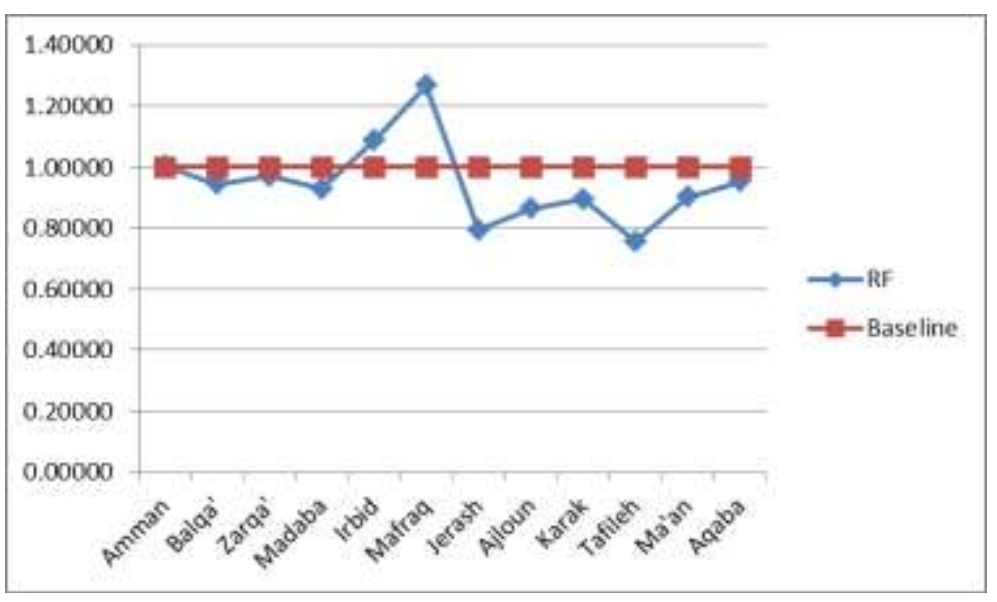

Figure 3. The calculated regional factor for Jordanian's region

Source: prepared by the author.

\section{Recommendations}

Increased economic growth in underdeveloped regions requires the expansion of financial decentralization by granting regional councils self-financing resources to finance their development projects. 
The central government should also continue to transfer a number of powers and functions to the administrative institutions in the regions. e.g (administrative decentralization).

It will be recommended also, that the central government should be continued to implement and develop development policies and programs that will accelerate economic growth in the regions, and improve living standards in the regions, such as industrial zones policy, reduce taxes and increase support for those affected in the least developed regions.

Funding: self-funded.

Author Contributions: conceptualization, Jameel Aljaloudi; data curation, Jameel Aljaloudi; formal analysis, Jameel Aljaloudi; funding acquisition, Jameel Aljaloudi; investigation, Jameel Aljaloudi; methodology, Jameel Aljaloudi; project administration, Jameel Aljaloudi; resources, Jameel Aljaloudi; software, Jameel Aljaloudi; supervision, Jameel Aljaloudi; validation, Jameel Aljaloudi; visualization, Jameel Aljaloudi; writing - original draft, Jameel Aljaloudi; writing - review \& editing, Jameel Aljaloudi.

\section{References}

1. Breau, S. and Saillant, R. (2016). Regional income disparities in Canada: exploring the geographical dimensions of an old debate. In Regional Studies, Regional Science, 3(1), 464-482. DOI: $10.1080 / 21681376.2016 .1244774$.

2. Department of Statistic (2010). Household expenditure and income survy 2010. Amman, Jordan. Available at: www.dos.gov.jo.

3. Department of Statistic (2017). Household expenditure and income survy 2017. Amman, Jordan. Available at: www.dos.gov.jo.

4. Fujita, M., Krugman, P and Venables, A. (2001). The Spatial Economy: Cities, Regions, and International Trade. Available at: https://mitpress.mit.edu/books/spatial-economy.

5. Gennaioli, N. and Porta, L. and De Silanes, F. and Shleifer, A. (2016). The Trend of Regional Income Disparity in China. Working Paper Series Document $N^{\circ}$ 193. Territorial Cohesion for Development Working Group. Journal of economic growth, 19, 259-309. DOI: 10.1007/s10887-014-9105-9.

6. Krugman, P. (1990). Increasing returns and economic geography. Working Paper, No. 3275.

7. Cambridge: National Bureau of Economic Research. Available at: https://pr.princeton.edu/pictures/gk/krugman/krugman-increasing_returns_1991.pdf.

8. Mansour, W. (2012). The Patterns and Determinants of Household Welfare Growth in Jordan 2002-2010. Policy Research Working $6249 . \quad$ Available at: https://documents.worldbank.org/.../en/416881468284337842/pdf/w ...

9. Midelfa, K. (2004). Does agglomeration explain regional income inequalities? Norwegian School of Economics and Business Administration and CEPR. Available at: www.etsg.org/ETSG2004/Papers/midelfart.pdf.

10. Mueller, H.(1976). Methoden zur analyse und Prognose. Taschenbuecher zzur Raumplanung, Hannover.

11. Myrdal, G. (1957). Economic Theory and Underdeveloped Regions. London: University Paperbacks, Methuen. Available at: https://www.coursehero.com/file/p64q11o/Myrdal-G-1957-Economic-theory...

12. Ray, D. (2007). Introduction to development theory. Journal of Economic Theory, 137(1), 1-10. Available at: https://www.sciencedirect.com/journal/journal-of-economic-theory/vol/137/issue/1.

13. Sheppard, E. et at. (2004). Introduction: reading economic geography. In Reading Economic Geography, Gary Bridge and Sophie Watson, eds. Oxford: Blackwell Publishing. Available at: https://bok.cc/book/2155658/0b4599.

14. UNDP and UNICEF (2015). An Empirical Analysis of Socio-economic Inequality in Jordan. Hashemite Kingdom of Jordan Deposit Number at Department of the National Library (2050/5/2015). Available at: https://www.undp.org/content/dam/jordan/docs/Poverty/UNDP Socio...

15. Villaverde, J. and Maza, A. (2009). Measurement of regional economic disparities. UNU-CRIS Working Papers W-2009/S. Available at: https://content.sciendo.com/view/journals/foli/14/2/article-p140.xml?

16. Wijerathna, D., Bandara, J., Smith, C., and Naranpanawa, A. (2014). Regional Disparities In Sri Lanka. Asia-Pacific Development Journal, 21(2), 77-102. DOI: 10.18356/93754059-en. 